large amount of disturbance by boaters and fishermen. I hope that it does not take another drought before the pelicans of Last Mountain Lake again breed successfully.

I would like to thank Clint Jorgenson for help with this article and Ed Driver and Phil Taylor for their encouragement to write it.

\section{EXOTIC BIRD IN SASKATOON}

CHRISTOPHER J. ESCOTT, 271

Sylvian Way, Saskatoon, Saskatchewan. S7H 5G1

On 18 July 1984, as I was engaged in strenuous soccer match, I sighted a most unusual bird. The game was being played on Fairview Field, which is bordered on east and north sides by the City of Saskatoon tree nursery. I saw the bird, and a glimpse was all I had, at about $2030 \mathrm{~h}$. The sun had set a short time earlier, but the sky was clear and the early dusk visibility was good, although colours were a bit hard to distinguish.

A single bird burst out of the Manitoba Maples on the east side of the field. It was the size and shape of a Mourning Dove, but perhaps more slender with smaller head and shorter neck. The tail was longish and tapered, with a suggestion of white corners. The most striking features were the large white wing patches near mid-wing from wrist to greater coverts, and the black area between these white patches and the wing tips.

The bird flew in a dipping, swooping semi-circle out over the sidelines of the field and back into the poplars at the northeast corner. At the crest of each swoop the tail fluttered and the bird uttered a clear whistled "klee klee klee..." at a rate of about 1 call/second. The calling continued briefly after the bird had re-entered the trees. It was not seen or heard again.

My initial reaction was "Wow! A Whited-winged Dove!" I was even more excited when I recalled hearing of an unconfirmed sighting of a White-winged Dove near Rice Lake in the summer of 1983. But I was nagged with doubts: a White-winged Dove should be chunkier than a Mourning Dove, have a less tapered tail, and sing like a hoarse domestic rooster. I checked Bent's Life Histories of North American Gallinaceous Birds, and Cottam and Trefethen's Whitewings, but couldn't resolve these doubts.

Then, several weeks later as I was walking in downtown Saskatoon, I heard a plaintive whistling noise coming through the open window of a car. I glanced in the back seat and saw a caged bird, a pet which is rather expensive but available in most local pet stores. It met the description of my mystery bird! It is the same length as a Mourning Dove; it has a long tapering tail; it is generally greyish in colour (males have bright yellow faces, but females are greyish all over); it has white wing patches which are a diagnostic feature in flight; and its call is a prolonged "queel queel" according to Slater's A Field Guide to Australian Birds. What was my mystery bird? I believe it was a female of the species Nymphicus hollandicus, a Cockatiel! I'm glad I've solved this riddle. I wonder if anyone else has seen strange things which may have been escaped exotics! 